\title{
PENGARUH MODEL PEMBELAJARAN DAN MOTIVASI BERPRESTASI TERHADAP HASIL BELAJAR PESERTA DIDIK KELAS XI IPA SMA NEGERI 6 TAKALAR
}

\author{
Hasnawati $^{1}$, Taty Sulastry², Muhammad Anwar ${ }^{3}$ \\ ${ }^{1}$ Guru Kimia SMAN 6 Takalar \\ ${ }^{2,3}$ Dosen Program Pascasarjana Universitas Negeri Makassar \\ Email: hasnawatihhasna@gmail.com
}

\begin{abstract}
ABSTRAK
Penelitian ini bertujuan untuk mengetahui pengaruh model pembelajaran dan motivasi berprestasi terhadap hasil belajar peserta didik kelas XI IPA SMA negeri 6 Takalar tahun pelajaran 2018/2019. Jenis penelitian ini adalah eksperimen semu dengan menggunakan desain faktorial $3 \times 3$. Populasi penelitian adalah seluruh peserta didik kelas XI IPA SMA Negeri 6 Takalar tahun pelajaran 2018/2019 yang berjumlah 95 orang. Pengambilan sampel diambil dari jumlah populasi yang ada sebagai subjek peneltian. Pengujian hipotesis dilakukan dengan menggunakan analisis one way Anova dan two way Anova. Hasil penelitian ini menunjukkan bahwa: (1) Ada pengaruh model pembelajaran terhadap hasil belajar peserta didik kelas XI IPA SMA Negeri 6 Takalar, (2) Ada pengaruh motivasi berprestasi terhadap hasil belajar peserta didik kelas XI IPA SMA Negeri 6 Takalar, (3) Tidak ada interaksi antara model pembelajaran dan motivasi terhadap hasil belajar peserta didik kelas XI IPA SMA Negeri 6 Takalar.
\end{abstract}

Kata kunci : Inkuiri Terbimbing, Pembelajaran Langsung, Discovery Learning, Motivasi Berprestasi dan Hasil Belajar.

\begin{abstract}
The study aims at examining the influence of learning model and achievement motivation on learning outcome of grade XI IPA student at SMAN 6 Takalar of academic year 2018/2019. The type of this study was quasi experiment using factorial $3 \times 3$ design. The research population was the entire student of grade XI IPA SMAN 6 Takalar of academic year $2018 / 2019$ with the total of 95 students. Sample was taken from the population as the research subject. Hypothesis test was conducted using one way Anova and two way Anova analysis. The results of the study reveal that (1) there is influence of learning model on learning outcome of grade XI IPA student at SMAN 6 Takalar, (2) there isi influence of achievement motivation on learning outcome of grade XI IPA student at SMAN 6 Takalar, and (3) there is no interaction between learning model and motivation on learning outcome of grade XI IPA students at SMAN 6 Takalar.
\end{abstract}

Keywords: guided inquiri, direct learning, discovery learning, achievement motivation, learning outcomes

\section{PENDAHULUAN}

Kemajuan ilmu pengetahuan dan teknologi yang mengalami perkembangan pesat, memberi tekanan pada prilaku manusia untuk memenuhi kebutuhan dan tuntutan hidupnya. Olehnya itu perlu 
pembentukan sumber daya manusia yang berkualitas, salah satunya adalah melalui penyelenggaraan pendidikan. Penentu keberhasilan pendidikan salah satunya adalah aspek pembelajaran.

Proses pembelajaran merupakan suatu kegiatan yang memiliki hakikat perencanaan atau desain untuk mencapai tujuan pendidikan yaitu membelajarkan peserta didik. Proses pembelajaran sangat dipengaruhi oleh kemampuan dan ketepatan guru dalam memilih dan menerapkan model pembelajaran (Sanjaya, 2006). Ketepatan memilih model pembelajaran diharapkan makin efektif dalam pencapaian tujuan pembelajaran. Dalam proses pembelajaran harus membangun komunikasi dua arah antara siswa dengan guru sehingga proses pembelajaran berjalan secara efektif. Mulyasa (2008) mengungkapkan bahwa pembelajaran yang efektif ditandai oleh sifatnya yang menekankan pada pemberdayaan peserta didik secara aktif dan interaktif.

Peran guru bukan hanya sebagai teladan semata bagi peserta didik yang diajarnya, akan tetapi juga berperan sebagai pengelolah pembelajaran atau agen pembelajaran (learning agent). Oleh karena itu, seorang guru harus memiliki empat kompetensi yaitu pedagogik, kepribadian, kompetensi sosial dan profesional, sesuai dengan pasal 8 UU RI No.14 tahun 2005. Untuk dapat memenuhi fungsi pembelajaran, guru dalam menjalankan aktivitas kerjanya di sekolah harus lebih fokus kepada tugastugas merancang dan mengelolah kegiatan belajar atau aktivitas peserta didik.

Dalam pembelajaran kimia peserta didik diarahkan untuk aktif, mencari tahu dan berbuat untuk meningkatkan pemahaman yang lebih dalam pada berbagai prinsip kimia yang akan membentuk kemampuan berpikir dalam memecahkan masalah yang di hadapi dalam kehidupan sehari-hari. Hal ini sejalan dengan salah satu tujuan dan prinsip pendekatan saintifik dalam kurikulum K-13 bahwa pembelajaran bertujuan untuk meningkatkan kemampuan intelek khususnya kemampuan berpikir tingkat tinggi peserta didik dalam memecahkan masalah dengan prinsip pembelajaran berpusat pada peserta didik.

Hasil observasi yang dilakukan di SMA Negeri 6 Takalar, menyatakan bahwa proses pembelajaran kimia umumnya masih berpusat pada guru, kurang memaksimalkan potensi yang dimiliki oleh peserta didik untuk mencapai tujuan pembelajaran kimia. Pelajaran kimia khususnya materi hidrokarbon memiliki konsep sangat luas dan bersifat abstrak yang berisi istilah-istilah yang jumlahnya banyak dan bervariasi dengan pemilihan model pembelajaran yang tidak tepat, menjadi penyebab sulit dan tidak menariknya belajar bagi peserta didik. Selain hasil observasi, hasil wawancara dengan guru kimia SMA Negeri 6 Takalar diperoleh informasi bahwa peserta didik cenderung menghafal konsep kimia sesuai yang ada dalam buku paket mereka. Contohnya ketika peserta didik diminta memberikan contoh selain yang tertera dalam buku paket atau diberikan soal yang alur pertanyaannya berbeda dengan contoh yang diberikan, peserta didik tidak dapat menjawabnya. Mereka menganggap bahwa soal yang diberikan tidak pernah dipelajari. Fenomena inilah yang kerap terjadi pada peserta didik karena tidaknya memahami konsep-konsep materi yang dipelajari. Dalam materi pokok hidrokarbon peserta didik diarahkan untuk mengenal penamaan senyawa hidrokarbon berdasarkan ciri khusus pada struktur yang dimiliki setiap golongannya, mengenal sifat-sifat senyawa hidrokarbon sehingga dibutuhkan kemampuan untuk memahami konsep dengan baik (Nurhayati, dkk, 2013).

Data analisis nilai ulangan materi hidrokarbon peserta didik kelas XI SMA Negeri 6 Takalar tahun pelajaran 2017/2018 menunjukkan bahwa dari standar KKM yang telah ditentukan 70 hanya $55 \%$ yang memperoleh nilai tuntas sedangkan $45 \%$ memperoleh nilai di bawah KKM. Demikian pula hasil penelitian Ramadhani (2017) mengidentifikasi tingkat kesulitan peserta 
didik pada materi hidrokarbon termasuk dalam kategori tinggi. Untuk itu, dalam mempelajari materi hidrokarbon diperlukan model pembelajaran yang tepat, sehingga peserta didik mudah memahami konsepkonsep materi pembelajaran dan meningkatkan hasil belajar peserta didik. Selain itu pemilihan model pembelajaran yang tepat dapat menciptakan kondisi pembelajaran yang dapat membuat siswa aktif dalam mengkonstruksi atau membangun sendiri pengetahuannya, sehingga pengetahuannya tentang hidrokarbon akan lebih lama diingat.

Berdasarkan kenyataan tersebut, maka guru harus mengatasi masalah khususnya proses pembelajaran kimia yaitu mencari dan mengupayakan model pembelajaran yang tepat, mendorong peserta didik lebih berperan aktif dan kreatif dalam proses pembelajaran sehingga pelajaran mudah dipahami dan dikuasai serta dapat meningkatkan hasil belajar peserta didik.

Ada beberapa model pembelajaran yang dapat digunakan untuk meningkatkan hasil belajar peserta didik diantaranya model pembelajaran penemuan dan pencarian yakni model pembelajaran berbasis kontruktivistik yang berorientasi kepada siswa (student centered approach), guna penggalian kompetensi yang dimiliki oleh peserta didik yaitu model pembelajaran inkuiri terbimbing dan discovery learning.

Model pembelajaran inkuiri terbimbing dapat membantu peserta didik mengembangkan keterampilan berpikir intelektual dan keterampilan lainnya, misalkan mengajukan pertanyaan atau menemukan jawaban sendiri yang berawal dari keingintahuan mereka. Pembelajaran model inkuiri terbimbing, pengetahuan bukanlah sejumlah fakta hasil dari mengingat, akan tetapi hasil dari proses menemukan sendiri, hal ini menunjukkan bahwa proses pembelajaran berpusat pada peserta didik. Dari hasil penelitian Sochibin (2009) menyatakan bahwa pembelajaran model inkuiri terbimbing dapat meningkatkan pemahaman konsep dan kemampuan berpikir peserta didik. Hal yang sama pada hasil penelitian Julistiawati (2013) bahwa penerapan model inkuiri terbimbing dapat meningkatkan kemampuan berpikir kritis dan pemahaman konsep IPA sehingga rata - rata memperoleh nilai yang baik.

Model pembelajaran discovery learning yang juga bertitik tolak dari proses penemuan yang prinsip pembelajarannya melatih peserta didik menemukan konsepkonsep dan prinsip-prinsip melalui proses mentalnya sendiri. Dalam menemukan konsep, peserta didik melakukan pengamatan, menggolongkan, membuat dugaan, menjelaskan, menarik kesimpulan dan sebagainya untuk menemukan beberapa konsep atau prinsip. Dengan teknik ini peserta didik diberikan kesempatan menemukan sendiri atau mengalami proses mental sendiri, sedangkan guru hanya membimbing dan memberikan intruksi. Hasil penelitian Sulistyowati (2012) menyatakan bahwa penerapan pembelajaran guided iscovery learning efektif dalam meningkatkan kemampuan pemecahan masalah. Demikian juga dari hasil penelitian Putrayasa (2014) yang mengemukakan bahwa model pembelajaran discovery learning dan minat belajar berpengaruh terhadap hasil belajar IPA siswa. Nugrahaeni dkk (2017) dalam penelitiannya menyimpulkan bahwa penerapan pembelajaran model discovery learning efektif dalam meningkatkan hasil belajar siswa dan keterampilan berpikir kritis siswa. Demikian pula hasil penelitihan Rahman (2010) menyatakan bahwa metode Discovery learning dapat meningkatkan pemahaman konsep peserta didik.

Selain pemilihan model pembelajaran yang tepat untuk meningkatkan hasil belajar peserta didik tidak terlepas pula dari motivasi berprestasi yang dimiliki peserta didik. Motivasi dalam kegiatan belajar adalah merupakan kekuatan yang dapat menjadi tenaga pendorong bagi peserta didik untuk menggali kompetensi yang ada dalam diri maupun dari luar dirinya untuk memperoleh hasil belajar yang maksimal. Sehingga motivasi untuk berprestasi 
merupakan salah satu faktor yang mendorong untuk menentukan keberhasilan peserta didik dalam belajar dan untuk mencapai harapan yang diinginkan. Mereka bekerja dengan giat, tangguh dalam tantangan, berorientasi menuju sukses, dan berorientasi ke depan, sehingga peserta didik yang memiliki motivasi berprestasi akan memberikan gambaran tentang hasil belajar karena kemungkinan besar dapat menyelesaikan tujuan pembelajaran yang akan dicapai. Motivasi berprestasi yang dimiliki setiap peserta didik dalam pembelajaran kimia didapatkan bervariasai yaitu ada peserta didik yang memiliki motivasi berprestasi tinggi, sedang dan rendah. Hasil penelitian Taiyeb (2011) menyimpulkan bahwa terdapat hubungan positif dan signifikan antara motivasi berprestasi dan hasil belajar.

Materi Hidrokarbon adalah materi yang sangat menarik, menyangkut senyawa yang memiliki bahan dasar karbon dan hidrogen. Sifat-sifat karbon yang unik seperti kemampuan untuk membuat rantai yang panjang menyebabkan banyaknya jenis-jenis senyawa hidrokarbon. Banyaknya jenis senyawa hidrokarbon, peserta didik dituntut dapat menemukan dan merumuskan sendiri sesuai indikator pencapaian yang diharapkan pada materi Hidrokarbon tersebut.

Berdasarkan dari uraian di atas, maka peneliti tertarik untuk melakukan sebuah penelitian tentang "Pengaruh Model Pembelajaran dan Motivasi Berprestasi Terhadap Hasil Belajar Peserta Didik Kelas XI IPA SMA Negeri 6 Takalar Studi Pada Materi Hidrokarbon".

\section{METODE PENELITIAN}

Jenis penelitian ini adalah eksperimen semu (quasy eksperiment) yang bertujuan untuk mengetahui pengaruh model pembelajaran dan motivasi berprestasi terhadap hasil belajar peserta didik kelas XI IPA SMA Negeri 6 Takalar Studi pada materi pokok Hidrokarbon.
Desain penelitian ini adalah desain faktorial (factorial design) yang dikategorikan sebagai desain faktorial $3 \times 3$ dengan menggunakan variabel bebas manipulatif yaitu model pembelajaran inkuiri terbimbing (A1), model pembelajaran langsung (A2) dan model pembeljaran discovery learning (A3) , sedangkan variabel bebas atributnya adalah motivasi berprestasi yang meliputi motivasi berprestasi tinggi (B1), motivasi berprestasi sedang (B2) dan motivasi berprstasi rendah (B3). Desain penelitian dapat dilihat pada tabel 1.

Tabel 1. Rancangan Faktorial 3 X 3 Untuk Mengetahui Hasil Belajar Peserta Didik

\begin{tabular}{|l|c|c|c|}
\hline \multirow{2}{*}{$\begin{array}{c}\text { Model } \\
\text { Pembelajaran (A) }\end{array}$} & \multicolumn{3}{|c|}{ Motivasi Berprestasi(B) } \\
\cline { 2 - 4 } & $\begin{array}{c}\text { Tinggi } \\
\left(\mathrm{B}_{1}\right)\end{array}$ & $\begin{array}{c}\text { Sedang } \\
\left(\mathrm{B}_{2}\right)\end{array}$ & $\begin{array}{c}\text { Rendah } \\
\left(\mathrm{B}_{3}\right)\end{array}$ \\
\hline $\begin{array}{l}\text { Inkuiri terbimbing } \\
\left(\mathrm{A}_{1}\right)\end{array}$ & $\mathrm{A}_{1} \mathrm{~B}_{1}$ & $\mathrm{~A}_{1} \mathrm{~B}_{2}$ & $\mathrm{~A}_{1} \mathrm{~B}_{3}$ \\
\hline $\begin{array}{l}\text { Discoveri } \\
\text { Learning }\left(\mathrm{A}_{2}\right)\end{array}$ & $\mathrm{A}_{2} \mathrm{~B}_{1}$ & $\mathrm{~A}_{2} \mathrm{~B}_{2}$ & $\mathrm{~A}_{2} \mathrm{~B}_{3}$ \\
\hline $\begin{array}{l}\text { Pembelajaran } \\
\text { Langsung }\left(\mathrm{A}_{3}\right)\end{array}$ & $\mathrm{A}_{3} \mathrm{~B}_{3}$ & $\mathrm{~A}_{3} \mathrm{~B}_{2}$ & $\mathrm{~A}_{3} \mathrm{~B}_{3}$ \\
\hline
\end{tabular}

Keterangan:

$\mathrm{A}_{1}=$ Model pembelajaran inkuiri terbimbing yang dibelajarkan pada peserta didik kelompok eksperimen 1.

$\mathrm{A}_{2}=$ Model pembelajaran langsung yang dibelajarkan pada peserta didik kelompok eksperimen 2.

$\mathrm{A}_{3}=\quad$ Model pembelajaran discovery learning yang dibelajarkan pada peserta didik kelompok eksperimen 3

$\mathrm{B}_{1}=$ Peserta didik yang memiliki motivasi berprestasi tinggi.

$\mathrm{B}_{2}=$ Peserta didik yang memiliki motivasi berprestasi sedang.

$\mathrm{B}_{3}=$ Peserta didik yang memiliki motivasi berprestasi rendah.

$\mathrm{A}_{1} \mathrm{~B}_{1}=$ Hasil belajar peserta didik melalui model pembelajaran inkuiri terbimbing dengan motivasi berprestasi tinggi.

$\mathrm{A}_{1} \mathrm{~B}_{2}=$ Hasil belajar peserta didik melalui model pembelajaran inkuiri terbimbing dengan motivasi berprestasi sedang.

$\mathrm{A}_{1} \mathrm{~B}_{3}=$ Hasil belajar peserta didik melalui model pembelajaran inkuiri terbimbing dengan motivasi berprestasi rendah. 
$\mathrm{A}_{2} \mathrm{~B}_{1}=$ Hasil belajar peserta didik melalui model pembelajaran langsung dengan motivasi berprestasi tinggi.

$\mathrm{A}_{2} \mathrm{~B}_{2}=$ Hasil belajar peserta didik melalui model pembelajaran langsung dengan motivasi berprestasi sedang.

$\mathrm{A}_{2} \mathrm{~B}_{3}=$ Hasil belajar peserta didik melalui model pembelajaran langsung dengan motivasi berprestasi rendah.

$\mathrm{A}_{3} \mathrm{~B}_{1}=$ Hasil belajar peserta didik melalui model pembelajaran discovery learning dengan motivasi berprestasi tinggi.

$\mathrm{A}_{3} \mathrm{~B}_{2}=$ Hasil belajar peserta didik melalui model pembelajaran discovery learning dengan motivasi berprestasi sedang.

$\mathrm{A}_{3} \mathrm{~B}_{3}=$ Hasil belajar peserta didik melalui model pembelajaran discovery learning dengan motivasi berprestasi rendah.

Populasi dalam penelitian ini adalah seluruh peserta didik kelas XI IPA SMA Negeri 6 Takalar tahun ajaran 2018/2019 yang terdiri dari tiga kelas yang berjumlah 95 peserta didik. Pengambilan sampel diambil dari jumlah populasi yang ada sebagai subjek penelitian yaitu kelas XI IPA1 dibelajarkan menggunakan model pembelajaran inkuiri terbimbing (kelas eksperimen 1), dan kelas XI IPA 3 dibelajarkan menggunakan model pembelajaran discovery learning (kelas eksperimen 2) serta kelas XI IPA2 dibelajarkan dengan menggunakan model pembelajaran langsung (kelas eksperimen $3)$.

Instrumen dalam penelitian ini adalah hasil belajar dan motivasi berprestasi dengan menggunakan tes tertulis yang diawali dengan tes motivasi berprestasi dan diakhiri dengan tes hasil belajar. Tes motivasi berprestasi sebanyak 40 item untuk mendapatkan data tentang motivasi berprestasi peserta didik. Setiap pernyataan disiapkan masing-masing 4 item jawaban yaitu Sangat Setuju (SS), setuju (S), Tidak Setuju (TS) dan Sangat Tidak setuju (STS). Tes hasil belajar peserta didik disusun dalam bentuk pilihan ganda sebanyak 20 soal yang telah divalidasi dengan item pilihan jawaban berjumlah 5(lima) buah dengan simbol pilihan a, b, c, d dan e, berdasarakan indikator atau tujuan pembelajaran yang diberikan seteleh proses pembelajaran selesai.

Analisis statistik deskrptif digunakan untuk mendeskripsikan secara umum hasil belajar peserta didik pada materi Hidrokarbon untuk setiap kelas eksperimen yang terdiri dari nilai rata-rata (mean), median, standar deviasi, skor tertinggi, skor terendah. Analisis data penelitian diolah dengan menggunakan program aplikasi statistik SPSS versi 18 for windows.

Hasil belajar peserta didik diukur dari kognitifnya, dianalisis dengan penentuan perolehan skor dan pengkategorian tingkat hasil belajar berdasarkan kriteria penilaian dengan menggunakan rumus Arikunto (2011), yaitu: Nilai $=($ skor perolehan $) /($ skor maksimum $) \mathrm{x}$ $100 \%$

Data perolehan skor nilai selanjutnya dibuat kategori, dengan mengacu pada kategori tuntas dan tidak tuntas berdasarkan Kriteria Kemampuan Minimal (KKM) di SMA Negeri 6 Takalar sesuai pada tabel 2.

Tabel 2. Kriteria Ketuntasan Minimum Peserta Didik

\begin{tabular}{|l|l|}
\hline Nilai & Kategori \\
\hline$\geq 70$ & Tuntas \\
$<70$ & TidakTuntas \\
\hline
\end{tabular}

Penelitian ini merupakan penelitian jenis pengembangan (Research and Development) yang bertujuan untuk mengembangkan bahan ajar elektronik Science Flashbook mata pelajaran IPA kelas VIII SMP pada Materi Pokok Partikel.

Analisis statistik infrensial digunakan untuk menguji kebenaran hipotesis yang diajukan sebelumnya. Sebelum melakukan analisis statistik difrensial, dilakukan uji prasyarat analisis yang meliputi uji normalitas dan uji homogenitas data dengan SPSS 18 for window.

\section{HASIL DAN PEMBAHASAN}

1. Deskripsi Motivasi Berprestasi dan Model Pembela 


\section{a. Deskripsi motivasi berprestasi}

Hasil analisis deskripsi motivasi berpestasi peserta didik kelas XI IPA SMA Negeri 6 Takalar sebelum diberikan perlakuan dengan menerapkan model pembelajaran inkuiri terbimbing, pembelajaran langsung dan discovery learning disajikan pada tabel 5.

Tabel 5. Deskripsi Motivasi Berprestasi Ketiga Kelas Model Pembelajaran

\begin{tabular}{|l|l|l|l|}
\hline Deskripsi & \multicolumn{3}{|l|}{ Kelas dengan Model Pembelajaran } \\
\cline { 2 - 4 } & $\begin{array}{l}\text { Inkuiri } \\
\text { Terbimbing }\end{array}$ & $\begin{array}{l}\text { Langsun } \\
\text { g }\end{array}$ & $\begin{array}{l}\text { Discovery } \\
\text { learning }\end{array}$ \\
\hline $\begin{array}{l}\text { Jumlah } \\
\text { Sampel }\end{array}$ & 33 & 33 & 29 \\
\hline Skor Ideal & 160 & 160 & 160 \\
\hline $\begin{array}{l}\text { Skor } \\
\text { Tertinggi }\end{array}$ & 126 & 143 & 133 \\
\hline $\begin{array}{l}\text { Skor } \\
\text { Terendah }\end{array}$ & 83 & 90 & 83 \\
\hline $\begin{array}{l}\text { Rata-rata } \\
\text { skor }\end{array}$ & 102,4 & 109,79 & 105,48 \\
\hline
\end{tabular}

Berdasarkan Tabel 5. deskripsi motivasi berprestasi belajar kimia, terlihat bahwa rata-rata motivasi berprestasi belajar kimia peserta didik yang tertinggi berada pada kelas yang sebelumnya diterapkan model pembelajaran langsung, kemudian kelas yang sebelumnya diterapkan model discovery learning dan yang terendah berada pada kelas yang sebelumnya diterapkan model pembelajaran inkuiri terbimbing. Adapun deskripsi dari data motivasi berprestasi belajar kimia untuk tiap sel desain penelitian pada tabel 6 .

Tabel 6. Distribusi Frekuensi Motivasi berprestasi Peserta Didik untuk Tiap Kelompok Sel

\begin{tabular}{|c|c|c|c|c|c|c|}
\hline \multirow{3}{*}{$\begin{array}{l}\text { Motiva } \\
\text { si } \\
\text { Berpre } \\
\text { stasi }\end{array}$} & \multicolumn{6}{|c|}{ Kelas dengan Model Pembelajaran } \\
\hline & \multicolumn{2}{|c|}{$\begin{array}{l}\text { Inkuiri } \\
\text { Terbimbing }\end{array}$} & \multicolumn{2}{|c|}{ Langsung } & \multicolumn{2}{|c|}{$\begin{array}{l}\text { Discovery } \\
\text { learning }\end{array}$} \\
\hline & $\begin{array}{l}\text { Freku } \\
\text { ensi }\end{array}$ & $\%$ & $\begin{array}{l}\text { Fre } \\
\text { kue } \\
\text { nsi }\end{array}$ & $\%$ & $\begin{array}{l}\text { Frek } \\
\text { uens } \\
\text { i }\end{array}$ & $\%$ \\
\hline Tinggi & 8 & $\begin{array}{l}24, \\
24\end{array}$ & 20 & $\begin{array}{l}60,6 \\
0\end{array}$ & 9 & $\begin{array}{l}31,0 \\
3\end{array}$ \\
\hline Sedang & 14 & $\begin{array}{l}42, \\
42\end{array}$ & 6 & 18,18 & 11 & $\begin{array}{l}33,3 \\
3\end{array}$ \\
\hline $\begin{array}{l}\text { Renda } \\
\mathrm{h}\end{array}$ & 11 & $\begin{array}{l}33, \\
34\end{array}$ & 7 & 21,21 & 9 & $\begin{array}{l}31,0 \\
3\end{array}$ \\
\hline
\end{tabular}

Pada Tabel 6 menunjukkan distribusi frekuensi motivasi berprestasi peserta didik terlihat bahwa peserta didik yang sebelumnya dibelajarakan model pembelajaran langsung memiliki motivasi berprestasi tinggi dibandingkan dengan peserta didik yang sebelumnya dibelajarkan dengan model pembelajaran inkuiri terbimbing dan discovery learning. Frekuensi motivasi berprestasi kategori sedang paling banyak berada pada kelas yang dibelajarakan dengan model inkuiri terbimbing.

b. Deskripsi hasil belajar kimia.

Hasil analisis deskripsi hasil belajar kimia peserta didik kelas XI IPA SMA Negeri 6 Takalar ditinjau dari model pembelajaran untuk ketiga kelas setelah dibelajarkan dengan model pembelajaran Inkuiri terbimbing, pembelajaran langsung dan pembelajaran discovery learning dapat dilihat pada tabel 7 .

Tabel 7. Deskripsi Hasil Belajar Kimia

\begin{tabular}{|l|l|l|l|}
\hline \multirow{2}{*}{ Deskripsi } & \multicolumn{3}{|l|}{ Kelas dengan Model pembelajaran } \\
\cline { 2 - 4 } & $\begin{array}{l}\text { Inkuiri } \\
\text { Terbimbing }\end{array}$ & Langsung & $\begin{array}{l}\text { Discovery } \\
\text { learning }\end{array}$ \\
\hline $\begin{array}{l}\text { Nilai } \\
\text { ideal }\end{array}$ & 100 & 100 & 100 \\
\hline $\begin{array}{l}\text { Jumlah } \\
\text { sampel }\end{array}$ & 33 & 33 & 29 \\
\hline $\begin{array}{l}\text { Nilai } \\
\text { tertinggi }\end{array}$ & 95 & 95 & 95 \\
\hline $\begin{array}{l}\text { Nilai } \\
\text { terendah }\end{array}$ & 55 & 35 & 50 \\
\hline Rerata & 78,18 & 70,15 & 72,59 \\
\hline
\end{tabular}

Tabel 7 mendeskripsikan nilai ratarata hasil belajar peserta didik pada kelas yang dibelajarkan dengan menggunakan model pembelajaran inkuiri terbimbing, pembelajaran langsung dan discovery learning. Pada tabel 7 terlihat rata-rata hasil belajar yang dibelajarkan dengan menggunakan inkuiri terbimbing $(78,18)$ lebih tinggi dibandingkan kelas yang dibelajarkan dengan menggunakan discovery learning $(72,59)$ dan terendah adalah kelas 
yang dibelajarkan dengan menggunakan model pembelajaran langsung $(70,15)$.

Nilai rata-rata hasil belajar peserta didik dikelompokkan dalam dua kategori berdasarkan Kriteria Ketuntasan Minimal (KKM) yang ditetapkan di SMA Negeri 6 Takalar sehingga diperoleh distribusi ketuntasan hasil belajar pada Tabel 8 .

Tabel 8. Distribusi Frekuensi Hasil Belajar Peserta Didik untuk Tiap Kelompok Sel

\begin{tabular}{|c|c|c|c|c|}
\hline \multirow{3}{*}{$\begin{array}{l}\text { Kelas } \\
\text { dengan } \\
\text { model } \\
\text { pembelaj } \\
\text { aran }\end{array}$} & \multicolumn{4}{|l|}{ Kriteria } \\
\hline & \multicolumn{2}{|c|}{$\begin{array}{l}\text { Tuntas } \\
(\mathrm{KKM} \geq 70)\end{array}$} & \multicolumn{2}{|c|}{$\begin{array}{l}\text { Tidak tuntas } \\
(\mathrm{KKM}<70)\end{array}$} \\
\hline & $\begin{array}{l}\text { Frekue } \\
\text { nsi }\end{array}$ & $\begin{array}{l}\text { Persent } \\
\text { ase }\end{array}$ & $\begin{array}{l}\text { frekue } \\
\text { nsi }\end{array}$ & $\begin{array}{l}\text { Persent } \\
\text { ase }\end{array}$ \\
\hline $\begin{array}{l}\text { Inkuiri } \\
\text { Terbimbi } \\
\text { ng }\end{array}$ & 30 & 90,9 & 3 & 9,1 \\
\hline $\begin{array}{l}\text { Langsun } \\
\mathrm{g}\end{array}$ & 21 & 63,6 & 12 & 36,4 \\
\hline $\begin{array}{l}\text { Discover } \\
\text { y } \\
\text { learning }\end{array}$ & 19 & 65,5 & 10 & 34,5 \\
\hline
\end{tabular}

Pada Tabel 8 menunjukkan distribusi frekuensi kategori ketuntasan hasil belajar kimia peserta didik terlihat bahwa kelas yang dibelajarkan menggunakan model inkuiri terbimbing memiliki ketuntasan hasil belajar paling tinggi dibandingkan dengan kelas yang dibelajarkan dengan menggunakan model pembelajaran langsung dan discovery learning. Hasil belajar peserta didik yang dibelajarkan dengan model pembelajaran inkuiri terbimbing dari 33 peserta didik $90,9 \%$ mendapat nilai tuntas dan $9,1 \%$ tidak tuntas, hasil belajar peserta didik yang dibelajarkan dengan menggunakan model discovery learning dari 29 peserta didik yang mencapai nilai tuntas $65,5 \%$ dan $34,5 \%$ tidak tuntas dan yang terendah adalah hasil belajar peserta didik yang dibelajarkan dengan model pembelajaran langsung dari 33 peserta didik $63,6 \%$ mencapai nilai tuntas dan $36,4 \%$ yang tidak tuntas.

Kategori hasil belajar kimia peserta didik ditinjau dari motivasi berprestasi dan model pembelajaran dibagi menjadi tiga kelompok yaitu hasil belajar kimia motivasi berprestasi tinggi, sedang dan rendah. Adapun deskripsi nilai hasil belajar kimia berdasarkan kategori motivasi berprestasi dan penerapan model pembelajaran dapat dilihat pada Tabel 9.

Tabel 9. Deskripsi Hasil Belajar Kimia Peserta Didik Berdasarkan Kategori Motivasi Berprestasi Kimia dan Model Pembelajaran

\begin{tabular}{|c|c|c|c|c|}
\hline \multirow{2}{*}{\multicolumn{2}{|c|}{$\begin{array}{l}\text { Kategori } \\
\text { Motivasi } \\
\text { Berprestasi } \\
\text { Kimia }\end{array}$}} & \multicolumn{3}{|c|}{$\begin{array}{l}\text { Kelas Dengan } \\
\text { Pembelajaran }\end{array}$} \\
\hline & & \multirow{2}{*}{$\begin{array}{l}\text { Inkuiri } \\
\text { Terbimb } \\
\text { ing } \\
100\end{array}$} & \multirow{2}{*}{$\begin{array}{l}\begin{array}{l}\text { Langsu } \\
\text { ng }\end{array} \\
100 \\
\end{array}$} & \multirow{3}{*}{$\begin{array}{l}\begin{array}{l}\text { Discov } \\
\text { ery } \\
\text { learnin } \\
\text { g }\end{array} \\
100 \\
9\end{array}$} \\
\hline \multicolumn{2}{|c|}{ Nilai Ideal } & & & \\
\hline \multirow[t]{4}{*}{$\begin{array}{l}\text { Tingg } \\
\text { i }\end{array}$} & $\begin{array}{l}\text { Jumlah } \\
\text { Sampe } \\
1\end{array}$ & 8 & 9 & \\
\hline & $\begin{array}{l}\text { Nilai } \\
\text { Tertin } \\
\text { ggi }\end{array}$ & 95 & 90 & 95 \\
\hline & $\begin{array}{l}\text { Nilai } \\
\text { Terend } \\
\text { ah }\end{array}$ & 75 & 65 & 65 \\
\hline & $\begin{array}{l}\text { Rata- } \\
\text { Rata }\end{array}$ & 86,25 & 81,11 & 81,67 \\
\hline \multirow[t]{4}{*}{$\begin{array}{l}\text { Seda } \\
\text { ng }\end{array}$} & $\begin{array}{l}\text { Jumlah } \\
\text { Sampe } \\
\text { l }\end{array}$ & 14 & 17 & 11 \\
\hline & $\begin{array}{l}\text { Nilai } \\
\text { Tertin } \\
\text { ggi }\end{array}$ & 85 & 80 & 90 \\
\hline & $\begin{array}{l}\text { Nilai } \\
\text { Terend } \\
\text { ah }\end{array}$ & 70 & 50 & 55 \\
\hline & $\begin{array}{l}\text { Rata- } \\
\text { Rata }\end{array}$ & 79,64 & 67,06 & \begin{tabular}{|l|}
72,27 \\
\end{tabular} \\
\hline \multirow[t]{4}{*}{$\begin{array}{l}\text { Rend } \\
\text { ah }\end{array}$} & $\begin{array}{l}\text { Jumlah } \\
\text { Sampe } \\
1\end{array}$ & 11 & 7 & 9 \\
\hline & $\begin{array}{l}\text { Nilai } \\
\text { Tertin } \\
\text { ggi }\end{array}$ & 80 & 75 & 75 \\
\hline & $\begin{array}{l}\text { Nilai } \\
\text { Terend } \\
\text { ah }\end{array}$ & 55 & 55 & 50 \\
\hline & $\begin{array}{l}\text { Rata- } \\
\text { Rata }\end{array}$ & 70,454 & 65,71 & 63,89 \\
\hline
\end{tabular}

Tabel 9 mendeskripsikan hasil belajar peserta didik berdasarkan model pembelajaran dan kategori motivasi 
berprestasi peserta didik. Pada Tabel 9 terlihat bahwa motivasi berprestasi tinggi, nilai rata-rata hasil belajar kimia peserta didik pada kelas yang dibelajarakan dengan menggunakan model pembelajaran inkuiri terbimbing $(86,25)$ lebih tinggi dibandingkan dengan kelas yang dibelajarakan dengan menggunakan model pembelajaran langsung $(81,11)$ dan discovery learning $(81,67)$. Untuk motivasi berprestasi sedang, nilai rata-rata hasil belajar kimia peserta didik pada kelas yang dibelajarakan dengan menggunakan model pembelajaran inkuiri terbimbing $(79,64)$ lebih tinggi dibandingkan dengan kelas yang dibelajarakan dengan menggunakan model pembelajaran langsung $(67,06)$ dan discovery learning (72,27). Sedangkan untuk motivasi berprestasi rendah, nilai ratarata hasil belajar kimia peserta didik pada kelas yang dibelajarakan dengan menggunakan model pembelajaran inkuiri terbimbing $(70,45) \quad$ lebih tinggi dibandingkan dengan kelas yang dibelajarakan dengan menggunakan model pembelajaran langsung $(65,71)$ dan discovery learning $(63,89)$.

\section{Pengujian Analisis Inferensial}

a. Uji normalitas

Uji normalitas dengan bantuan program SPSS versi 18 for windows dengan analisis Kolmorov-Smirnov digunakan untuk mengetahui apakah data sampel yang diteliti berasal dari populasi yang terdistribusi normal. Kriteria pengujian: jika signifikansi $(p)>\alpha=0,05$ maka data tersebut berasal dari populasi yang terdistribusi normal artinya setiap peserta didik dalam populasi memiliki tingkatan motivasi berprestasi dan tingkat pengetahuan yang berbeda-beda dan dan apabila signifikansi (p) $<\alpha=0,05$ maka data tersebut berasal dari populasi yang tidak terdistribusi normal artinya semua peserta didik dalam populasi memiliki tingkatan motivasi berprestasi dan tingkat pengetahuan yang sama. Hasil pengujian normalitas untuk motivasi berprestasi belajar kimia dapat dilihat pada tabel 4.6 dan kelas model pembelajaran (inkuiri terbimbing, pembelajaran langsung dan discovery learning) dapat dilihat pada tabel 10 .

Tabel 10. Hasil Uji Normalitas Berprestasi Tinggi, Berprestasi Sedang dan Berprestasi Rendah.

\begin{tabular}{|l|l|l|l|l|}
\hline \multirow{2}{*}{} & \multirow{2}{*}{$\begin{array}{l}\text { Motivasi } \\
\text { Berprestasi }\end{array}$} & \multicolumn{3}{|l|}{$\begin{array}{l}\text { Kolmogorov- } \\
\text { Smirnov }^{\mathrm{a}}\end{array}$} \\
\cline { 3 - 5 } & & Statistic & Df & Sig. \\
\hline \multirow{2}{*}{$\begin{array}{l}\text { Tes Hasil } \\
\text { Motivasi } \\
\text { berprestasi }\end{array}$} & Tinggi & .139 & 33 & .109 \\
\cline { 2 - 5 } & Sedang & .107 & 33 & $.200^{*}$ \\
\cline { 2 - 5 } & Rendah & .071 & 29 & $.200^{*}$ \\
\hline
\end{tabular}

Tabel 11. Hasil Uji Normalitas Nilai Hasil Belajar Peserta Didik yang Dibelajarkan Model Inkuiri Terbimbing, Pembelajaran Langsung dan Discovery Learning

\begin{tabular}{|l|l|l|l|l|}
\hline \multirow{2}{*}{$\begin{array}{l}\text { Metode } \\
\text { Helajil }\end{array}$} & Pembelajaran & \multicolumn{3}{|c|}{ Kolmogorov-Smirnov } \\
\cline { 3 - 5 } & $\begin{array}{l}\text { Model } \\
\text { Inquiry }\end{array}$ & .141 & 33 & .093 \\
\cline { 2 - 5 } & $\begin{array}{l}\text { Model } \\
\text { Pembelajaran } \\
\text { Langsung }\end{array}$ & .130 & 33 & .174 \\
\cline { 2 - 5 } & $\begin{array}{l}\text { Model } \\
\text { Discovery } \\
\text { learning }\end{array}$ & .098 & 29 & $.200^{*}$ \\
\hline
\end{tabular}

Berdasarkan tabel 10 untuk kelas yang dibelajarkan model pembelajaran inkuiri terbimbing nilai signifikansi $0,93>\alpha$ $=0,05$, dan kelas yang dibelajarkan model pembelajaran langsung nilai signifikansi $0,174>\alpha=0,05$ serta kelas yang dibelajarkan dengan model discovery learning nilai signifikansi $0,20>\alpha=0,05$. Maka dapat disimpulkan bahwa hasil belajar peserta didik pada kelas model inkuiri terbimbing, pembelajaran langsung dan discovery learning adalah terdistribusi normal.

Tabel 11 menunjukkan uji normalitas untuk motivasi berprestasi tinggi nilai signifikansi $0,109>\alpha=0,05$ dan untuk motivasi berprestasi sedang nilai signifikansi $0,200>\alpha=0,05$ serta motivasi berprestasi rendah nilai signifikansi $0,200>\alpha=0,05$. Maka dapat disimpulkan bahwa untuk 
motivasi berprestasi tinggi, sedang dan rendah adalah terdistribusi normal.

b. Uji Homogenitas

Uji homogenitas digunakan untuk mengetahui apakah beberapa varian populasi data sama atau tidak. Kriteria pengujiannya, jika signifikansi(p) $>\alpha=0,05$ maka dapat dikatakan bahwa varian data adalah sama atau homogen. Untuk hasil pengujian homogenitas dengan rumus Levene's test of eqality of error variance dengan bantuan Program SPSS versil8 for windows. Hasil pengujian homogenitas untuk model pembelajaran dan motivasi berprestasi belajar kimia dapat dilihat pada tabel 12 .

Tabel 12. Hasil Uji homogenitas untuk hasil belajar dengan model pembelajaran dan motivasi berprestasi belajar kimia.

\begin{tabular}{llcc}
\hline $\begin{array}{l}\text { Levene } \\
\text { Statistic }\end{array}$ & df1 & df2 & Sig. \\
\hline $\mathbf{1 . 9 1 1}$ & $\mathbf{8}$ & $\mathbf{8 6}$ & $\mathbf{. 0 6 9}$ \\
\hline
\end{tabular}

Tabel 12 data homogenitas hasil belajar dengan model pembelajaran dan motivasi berprestasi belajar kimia menunjukkan nilai signifikasi $0,069>\alpha=$ 0,05 maka hasil belajar peserta didik dengan model pembelajaran dan motivasi berprestasi belajar kimia berasal dari populasi yang homogen.

c. Uji Hipotesis

Setelah terpenuhinya uji prasyarat analisis variansi yang terdiri dari uji normalitas dan uji homogenitas varians, maka dilanjutkan dengan uji hipotesis. Hasil pengujian hipotesis merupakan jawaban dari rumusan masalah yang telah dibuat dan pengujian hipotesis dengan menggunakan analisis anova. Hasil uji hipotesis untuk model pembelajaran dan motivasi berprestasi terhadap hasil belajar serta interaksi antara model pembelajaran dan motivasi berprestasi terhadap hasil belajar sebagai berikut.

1). Uji hipotesis pengaruh model pembelajaran terhadap hasil belajar dengan menggunakan analisis variansi satu jalur
(One Way Anova) dapat dilihat pada tabel 13.

Tabel 13. Hasil Pengujian Hipotesis Model Pembelajaran Terhadap Hasil Belajar Dengan Analisis One Way Anova

\begin{tabular}{|l|l|l|l|l|}
\hline $\begin{array}{l}\text { Sumber } \\
\text { Variasi }\end{array}$ & JK & dK & RK & Sig. \\
\hline $\begin{array}{l}\text { Antar } \\
\text { Kelompok }\end{array}$ & 1855.745 & 2 & 927.873 & $\mathbf{0 , 0 0 0}$ \\
\hline $\begin{array}{l}\text { Dalam } \\
\text { Kelompok }\end{array}$ & 8766.886 & 92 & 95.292 & \\
\hline Total & 10622.632 & 94 & & \\
\hline
\end{tabular}

Hasil analisis menunjukkan bahwa nilai signifikan $0,000<\alpha=0,05$, berarti $\mathrm{H}_{0}$ ditolak dan $\mathrm{H}_{1}$ diterima artinya terdapat perbedaan hasil belajar peserta didik kelas XI IPA SMA Negeri 6 Takalar yang dibelajarkan dengan menggunakan model pembelajaran inkuiri terbimbing, pembelajaran langsung dan model pembelajaran discovery learning pada materi Hidrokarbon.

Untuk melihat manakah yang secara signifikan memberikan pengaruh terhadap hasil belajar peserta didik berdasarkan nilai rata-rata masing-masing sel maka dilakukan uji lanjutan (Post Hoc). Hasil uji lanjutan (Post Hoc) dapat dilihat pada tabel 14.

Tabel 14. Hasil Uji Post Hoc (Uji Lanjutan) Variabel Model Pembelajaran

\begin{tabular}{|c|c|c|c|}
\hline & $\begin{array}{lr}\text { (I) } & \text { Model } \\
\text { Pembelajaran }\end{array}$ & $\begin{array}{l}\text { (J) Modal } \\
\text { Pembelajaran }\end{array}$ & Sig. \\
\hline \multirow[t]{6}{*}{ Scheffe } & \multirow[t]{2}{*}{$\begin{array}{l}\text { Model } \\
\text { Inquiry } \\
\text { Terbimbing }\end{array}$} & $\begin{array}{l}\text { Model } \\
\text { Pembelajaran } \\
\text { Langsung }\end{array}$ & .003 \\
\hline & & $\begin{array}{l}\text { Model } \\
\text { Discovery } \\
\text { learning }\end{array}$ & .051 \\
\hline & \multirow{2}{*}{$\begin{array}{l}\text { Model } \\
\text { Pembelajaran } \\
\text { Langsung }\end{array}$} & Model Inquiry & .003 \\
\hline & & $\begin{array}{l}\text { Model } \\
\text { Discovery } \\
\text { learning }\end{array}$ & .681 \\
\hline & \multirow{2}{*}{$\begin{array}{l}\text { Model } \\
\text { Discovery } \\
\text { learning }\end{array}$} & Model Inquiry & .051 \\
\hline & & $\begin{array}{l}\text { Model } \\
\text { Pembelajaran } \\
\text { Langsung }\end{array}$ & .681 \\
\hline
\end{tabular}


Berdasarkan Tabel 14 hasil uji lanjutan (Post Hoc) menunjukkan bahwa model inkuiri terbimbing dengan model pembelajaran langsung diperoleh nilai signifikan $0.003<0,05$ berarti rataan hasil belajar yang diperoleh antara model pembelajaran inkuiri terbimbing dengan pembelajaran langsung berbeda secara signifikan. Sedangkan antara model pembelajaran inkuiri terbimbing dengan model discovery learning diperoleh nilai signifikan $0,05=\alpha$ berarti rataan hasil belajar yang diperoleh antara model pembelajaran inkuiri terbimbing dengan pembelajaran discovery learning tidak berbeda secara signifikan. Dapat disimpulkan bahwa model pembelajaran inkuiri terbimbing dan discovery learning secara signifikan berpengaruh terhadap hasil belajar peserta didik kelas XI IPA SMA Negeri 6 Takalar pada materi Hidrokarbon.

2). Uji hipotesis pengaruh motivasi berprestasi terhadap hasil belajar dengan menggunakan analisis variansi satu jalur (One Way Anova) dapat dilihat pada tabel 15.

Tabel 15. Hasil Pengujian Hipotesis Dengan Menggunakan Analisis Varians Satu Arah/Jalur (analisis One Way Anova)

\begin{tabular}{|l|l|}
\hline Sumber Variasi & Sig. \\
\hline Antar kelompok & $\mathbf{0 , 0 0 0}$ \\
\hline Dalam Kelompok & \\
\hline Total & \\
\hline
\end{tabular}

Tabel 14 menunjukkan bahwa nilai signifikan $0,00<\alpha=0,05$ berarti $\mathrm{H}_{0}$ ditolak dan $\mathrm{H}_{1}$ diterima artinya terdapat perbedaan hasil belajar peserta didik kelas XI IPA SMA Negeri 6 Takalar yang dibelajarkan dengan menggunakan model pembelajaran inkuiri terbimbing, pembelajaran langsung dan model pembelajaran discovery learning pada materi Hidrokarbon.

Untuk melihat manakah yang secara signifikan memberikan pengaruh terhadap hasil belajar peserta didik berdasarkan nilai rata-rata masing-masing sel maka dilakukan uji lanjutan (Post Hoc). Hasil uji lanjutan (Post Hoc)dapat dilihat pada tabel 15.

Tabel 16. Hasil Uji Post Hoc (Uji Lanjutan) Variabel Motivasi Berprestasi

\begin{tabular}{|c|c|c|c|}
\hline & $\begin{array}{l}\text { (I) } \\
\text { Motivasi } \\
\text { Berprestasi }\end{array}$ & $\begin{array}{l}\text { (J) Motivasi } \\
\text { Berprestasi }\end{array}$ & Sig. \\
\hline \multirow[t]{6}{*}{ Scheffe } & \multirow[t]{2}{*}{$\begin{array}{l}\text { Motivasi } \\
\text { Berprestasi } \\
\text { Tinggi }\end{array}$} & $\begin{array}{l}\text { Motivasi } \\
\text { Berpretasi } \\
\text { Sedang }\end{array}$ & .502 \\
\hline & & $\begin{array}{l}\text { Motivasi } \\
\text { Berprestasi } \\
\text { Rendah }\end{array}$ & .000 \\
\hline & \multirow[t]{2}{*}{$\begin{array}{l}\text { Motivasi } \\
\text { Berpretasi } \\
\text { Sedang }\end{array}$} & $\begin{array}{l}\text { Motivasi } \\
\text { Berprestasi } \\
\text { Tinggi }\end{array}$ & .502 \\
\hline & & $\begin{array}{l}\text { Motivasi } \\
\text { Berprestasi } \\
\text { Rendah }\end{array}$ & .003 \\
\hline & \multirow[t]{2}{*}{$\begin{array}{l}\text { Motivasi } \\
\text { Berprestasi } \\
\text { Rendah }\end{array}$} & $\begin{array}{l}\text { Motivasi } \\
\text { Berprestasi } \\
\text { Tinggi }\end{array}$ & .000 \\
\hline & & $\begin{array}{l}\text { Motivasi } \\
\text { Berpretasi } \\
\text { Sedang }\end{array}$ & .003 \\
\hline
\end{tabular}

Berdasarkan Tabel 15 hasil uji lanjutan (Post Hoc) menunjukkan bahwa hasil belajar peserta didik yang memiliki motivasi berpretasi tinggi dengan peserta didik yang memiliki motivasi berprestasi sedang nilai signifikan diperoleh $0,50>\alpha=$ 0,05 berarti hasil belajar yang memiliki motivasi berprestasi tinggi tidak berbeda secara signifikan dengan hasil belajar peserta didik yang memiliki motivasi berprestasi sedang. Sedangkan hasil belajar peserta didik yang memiliki motivasi berprestasi tinggi dengan hasil belajar peserta didik yang memiliki motivasi berprestasi rendah diperoleh nlai signifikan $0,00<\alpha=0,05$ berarti hasil belajar yang memiliki motivasi berprestasi tinggi berbeda secara signifikan dengan hasil belajar peserta didik yang memiliki motivasi berprestasi rendah. Dapat disimpulkan bahwa peserta didik yang memiliki motivasi berprestasi tinggi dan sedang secara signifikan berpengaruh terhadap hasil belajar peserta didik kelas XI IPA SMA Negeri 6 Takalar pada materi Hidrokarbon. 
3). Uji hipotesis interaksi antara model pembelajaran dan motivasi berprestasi terhadap hasil belajar dengan menggunakan analisis variansi dua jalur (Two Way Anova) dapat dilihat pada tabel 16.

Tabel 16. Hasil Pengujian Hipotesis dengan Menggunakan Analisis Varians Dua Arah/Jalur (analisis Two Way Anova)

\begin{tabular}{|l|l|}
\hline Sumber & Sig. \\
\hline Model Pembelajaran (A) & 0.001 \\
\hline Motivasi Berprestasi (B) & 0.000 \\
\hline Interaksi (AB) & $\mathbf{0 . 3 3 0}$ \\
\hline
\end{tabular}

Tabel 16 menunjukkan bahwa nilai signifikan $0,33>\alpha=0,05$ berarti $\mathrm{H}_{1}$ ditolak dan $\mathrm{H}_{0}$ diterima artinya tidak adak interaksi antara model pembelajaran dan motivasi berprestasi dalam mempengaruhi hasil belajar peserta didik kelas XI IPA SMA Negeri 6 Takalar pada materi Hidrokarbon. Hipotesis ketiga juga dapat dijelaskan dengan grafik pada gambar 1 .

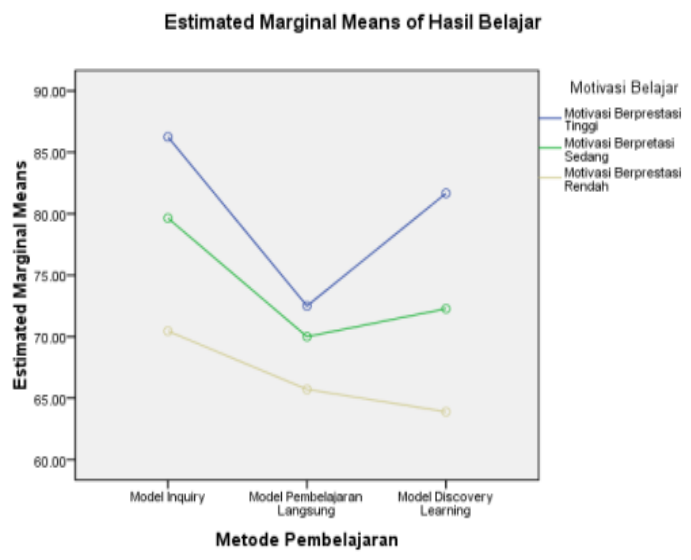

Gambar 1. Interaksi Antara Model Pembelajaran dan Motivasi Berprestasi Terhadap Hasil Belajar Peserta Didik Kelas XI IPA SMA Negeri 6 Takalar

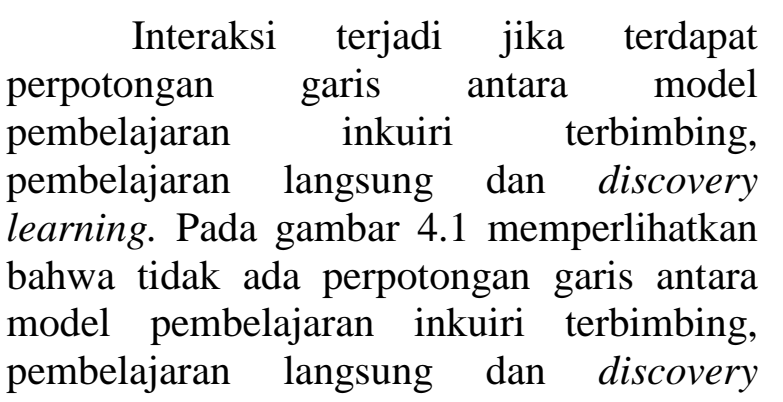

learning maka dapat disimpulkan bahwa tidak ada interaksi antara model pembelajaran dan motivasi berprestasi dalam mempengaruhi hasil belajar peserta didik kelas XI IPA SMA Negeri 6 Takalar pada materi Hidrokarbon.

Penelitian ini dilakukan untuk mengetahui pengaruh model pembelajaran dan motivasi berprestasi terhadap hasil belajar peserta didik kelas XI IPA SMA Negeri 6 Takalar pada pokok bahasan Hidrokarbon. Berdasarkan pada rumusan masalah bahwa pengaruh perlakuan terhadap hasil belajar kimia peserta didik secara operasional dapat dilihat dari perbedaan hasil belajar kimia peserta didik dari kelompok yang dibandingkan. Sehingga dalam pembahasan ini perbedaan-perbedaan tersebut akan dikembalikan ke pengertian pengaruh. Dalam artian bahwa jika ada perbedaan maka ada pengaruh

\section{Pengaruh model pembelajaran terhadap hasil belajar kimia peserta didik kelas XI IPA SMA Negeri 6 takalar pada pokok bahasan Hidrokarbon.}

Berdasarakan analisis statistik deskripsi perolehan nilai rata-rata hasil belajar peserta didik yang dibelajarkan dengan menggunakan model pembelajaran inkuiri terbimbing, pembelajaran langsung dan discovery learning yang tertinggi adalah nilai rata-rata hasil belajar peserta didik yang dibelajarkan dengan model inkuiri terbimbing. Hal ini menunjukkan bahwa model pembelajaran inkuiri terbimbing lebih baik jika dibandingkan dengan model pembelajaran langsung dan discovery learning.

Hasil analisis inferensial menunjukkan adanya perbedaan siginifikan hasil belajar peserta didik yang dibelajarkan dengan model inkuiri terbimbing, pembelajaran langsung dan pembelajaran discovery learning pada materi Hidrokarbon kelas XI IPA SMA Negeri 6 Takalar. Adanya perbedaan hasil belajar peserta didik 
berarti ada pengaruh model pembelajaran terhadap hasil belajar peserta didik.

$$
\text { Secara inferensial model }
$$
pembelajaran yang mempengaruhi hasil belajar peserta didik kelas XI IPA SMA Negeri 6 Takalar adalah model pembelajaran inkuiri terbimbing dan discovery learning. Model pembelajaran inkuiri terbimbing dan discovery learning merupakan model pembelajaran yang menuntut peserta didik untuk menemukan sendiri pengetahuannya dengan kata lain menempatkan peserta didik sebagai subjek atau pusat pembelajaran (student centred) di dalam kelas. Kedua model pembelajaran ini memiliki potensi yang amat besar untuk membuat pengalaman belajar yang lebih menarik dan bermakna bagi peserta didik dalam menemukan konsep dan hasil yang diperoleh akan bertahan lama dan tidak mudah dilupakan. Hasil penelitian Oghenevwedw (2010) menyimpulkan bahwa model discovery learning dan inkuiri efektif dan unggul dalam mengajar biologi. Sedangkan model pembelajaran langsung adalah model pembelajaran dengan cara menyampaikan pelajaran yang ditransformasikan langsung oleh guru kepada peserta didik, sehingga kurang memberikan kesempatan kepada peserta didik untuk memproses dan memahami informasi yang disampaikan. Hasil analisis dalam penelitian ini dinyatakan bahwa model pembelajaran langsung tidak mempengaruhi hasil belajar peserta didik. Hal ini sejalan dengan penelitian Mubarok (2014) bahwa hasil belajar peserta didik yang dibelajarkan dengan model discovery learning lebih tinggi dibandingkan model pembelajaran langsung.

Hasil analisis data penelitian hasil belajar peserta didik pada setiap kelas eksperimen menunjukkan bahwa rata-rata hasil belajar peserta didik yang paling tinggi adalah hasil belajar peserta didik yang dibelajarkan dengan model inkuiri terbimbing, kemudian hasil belajar dari peserta didik yang dibelajarkan dengan model discovery learning dan yang terendah adalah hasil belajar dari peserta didik yang dibelajarkan dengan model pembelajaran langsung. Demikian pula kategori ketuntasan belajar peserta didik yang dibelajarkan dengan model pembelajaran inkuiri terbimbing lebih tinggi dibandingkan ketuntasan belajar peserta didik yang dibelajarkan dengan model discovery learning dan model pembelajran langsung.

Banyaknya peserta didik yang memperoleh nilai tuntas setelah dibelajarkan dengan model pembelajaran inkuiri terbimbing dibandingkan dengan model pembelajaran discovery learning karena model pembelajaran inkuiri terbimbing mengarahkan peserta didik pada penyelidikan dalam mencari atau memahami suatu informasi dengan bantuan guru. Dengan model inkuiri terbimbing peserta didik dapat menemukan sendiri pengetahuannya melalui kegiatan belajar yang melibatkan kemampuan menyelidiki secara sistematis,kritis dan analitis. Selain itu pada model pembelajaran inkuiri terbimbing permasalahannya bukan hasil rekayasa guru sehingga peserta didik harus mengarahkan pikiran dan keterampilannya untuk mendapatkan temuan di dalam masalah melalui proses penelitian. Peserta didik mendapatkan pembelajaran bermakna atas temuan yang didapatkan sendiri. Hasil penelitian ini relevan yang dikemukakan Shuaili (2001) bahwa inkuiri terbimbing lebih efisien untuk meningkatkan keterampilan berpikir ketika belajar dibandingkan dengan discovery learning.

Model pembelajaran discovery learning merupakan model pembelajaran penemuan pula, dimana peserta didik dalam mencapai tujuan pembelajaran bimbingan guru sangat terbatas bahkan sama sekali tanpa bimbingan. Model pembelajaran ini menekankan pada belajar mandiri dan penemuan konsep atau prinsip yang didasarkan pada pengalaman belajar sebelumnya (Ilahi, 2012) dalam hal ini menggabungkan pengetahuan yang sudah ada dengan pengetahan baru dalam proses penemuan. 
Perbedaan hasil belajar dari kedua model pembelajaran ini disebabkan pula dari sintaks masing-masing model pembelajaran yang dihubungkan dengan kemampuan berpikir peserta didik, dimana pada model pembelajaran inkuiri terbimbing tahap penyajian masalah dan membuat hipotesis yang diberikan tidak lepas dari bimbingan guru. Pada model discovery learning pada tahap stimulasi dan identifikasi masalah, peserta didik dalam mencari solusi penyelesaiannya menggerahkan seluruh kemampuannya sendiri disebabkan frekuensi bimbingan guru terbatas atau bahkan tidak sama sekali. Dampaknya, dapat menyebabkan peserta didik yang memiliki kemampuan kognitif rendah tanpa bimbingan guru yang maksimal maka akan mengalami kesulitan dalam menemukan suatu konsep. Ada beberapa penelitian yang relevan dengan hal di atas yaitu: Greenwald (2014) menyimpulkan bahwa model pembelajaran inkuiri memberi keuntungan lebih besar dalam meningkatkan kemampuan analisis, kesimpulan, dan interpretasi peserta didik; Fajariyah (2016) model pembelajaran inkuiri terbimbing dapat meningkatkan kemampuan dan prestasi belajar peserta didik; Sumarni, dkk (2017) bahwa model pembelajaran inkuiri terbimbing dapat meningkatkan hasil belajar kognitif peserta didik; Putrayasa (2014) bahwa model pembelajaran discovery learning sangat siginifikan dalam meningkatkan hasil belajar peserta didik.

Sementara model pembelajaran langsung hasil belajarnya sangat rendah disebabkan pembelajaran berpusat pada guru sehingga peserta didik hanya memiliki sedikit kesempatan untuk terlibat secara aktif. Selain itu, dalam pembelajaran langsung tidak ada interaksi antara peserta didik yang mudah atau cepat memahami suatu pembelajaran dengan peserta didik yang kurang atau lambat memahami pembelajaran, sehingga peserta didik yang memiliki kemampuan lebih tinggi tidak dapat membantu peserta didik lainnya yang memiliki kemampuan rendah. Peserta didik yang memiliki kemampuan kognitif rendah akan menyebabkan semakin kurang atau tidak ada motivasi belajarnya karena bosan, dan teralihkan perhatiannya. Oleh karena adanya perbedaan hasil belajar peserta didik yang dibelajarkan dengan model pembelajaran inkuiri terbimbing, pembelajaran langsung dan discovery learning, maka dapat dikatakan ada pengaruh model pembelajaran terhadap hasil belajar peserta didik kelas XI IPA SMA Negeri 6 Takalar.

\section{Pengaruh motivasi berprestasi terhadap hasil belajar kimia peserta didik kelas XI IPA SMA Negeri 6 takalar pada pokok bahasan Hidrokarbon.}

Berdasarkan hasil penelitian menunjukkan adanya perbedaan hasil belajar peserta didik yang memiliki motivasi berprestasi tinggi, sedang dan rendah pada peserta didik kelas XI IPA SMA Negeri 6 Takalar. Peserta didik yang memiliki motivasi berprestasi tinggi memperoleh hasil belajar yang tinggi pula dibandingkan kelompok peserta didik yang memiliki motivasi berprestasi sedang dan rendah. Dari hasil analisis inferensial menunjukkan ada perbedaan hasil belajar peserta didik yang memilki motivasi berprestasi tinggi, sedang dan rendah pada materi pokok Hidrokarbon kelas XI IPA SMA Negeri 6 Takalar.

Hal ini ditunjukkan dari rata-rata hasil belajar peserta didik yang dibelajarkan dengan model pembelajaran inkuiri terbimbing, pembelajaran langsung maupun discovery learning secara umum dari ratarata hasil belajar peserta didik dari ketiga model pembelajaran bahwa peserta didik yang memiliki hasil belajar yang tinggi diperoleh oleh peserta didik yang memiliki motivasi berprestasi tinggi, peserta didik yang memiliki hasil belajar yang sedang diperoleh oleh peserta didik yang memiliki motivasi berprestasi sedang dan peserta didik yang memiliki hasil belajar yang rendah diperoleh oleh peserta didik yang memiliki motivasi berprestasi rendah.

Perbedaan hasil belajar ini terjadi karena peserta didik yang memiliki motivasi berprestasi tinggi akan senantiasa 
mencurahkan segenap kemampuannya untuk mencapai hasil belajar yang baik dengan meningkatkan frekuensi belajarrnya secara intensif sehingga memperoleh hasil belajar yang maksimal. Dengan kata lain bahwa peserta didik yang memiliki motivasi berprestasi tinggi akan belajar lebih lama, memiliki target apa yang harus dicapai dan cenderung mengalami kesuksesan dalam mengerjakan tugas-tugas di sekolah. Hal tersebut diperkuat pendapat Weiner (Wuryani,1988) bahwa peserta didik yang bermotivasi akan melakukan tugas lebih lama daripada peserta didik yang kurang motivasi berprestasinya, bahkan mereka setelah mengalami kegagalan dan menghubungkan kegagalannya tidak atau kurang berusaha. Peserta didik yang memiliki motivasi berprestasi tinggi menampakkan minat dan perhatian penuh terhadap tugas- tugas belajar kimia yang diberikan. Sedangkan peserta didik yamg memiliki motivasi berprestasi sedang menampakkan hampir sama dengan peserta didik yang memiliki motivasi berprestasi tinggi hanya dalam proses kegiatan pembelajaran menunjukkan kurang komunikatif selama pembelajaran berlangsung. Sementara peserta didik yang memiliki motivasi berprestasi rendah menampakkan keengganganan, tidak suka tantangan, kurang fokus pada pelajaran serta cepat merasa puas atas nilai yang diperolenhya.

Hasil penelitian ini relevan dengan hasil penelitian Taiyeb (2012) yang menyimpulkan bahwa ada korelasi yang signifikan antara motivasi berprestasi dengan prestasi belajar. Motivasi berprestasi dapat digunakan sebagai prediktor atas prestasi belajar yaitu semakin tinggi nilai motivasi berprestasi, maka semakin tinggi pula prestasi belajar yang akan dicapai. Adanya motivasi akan memberi semangat sehingga peserta didik tergugah untuk belajar, peserta didik menjadi aktif, sibuk, dan tertarik, motivasi menopang upaya dan menjaga agar semangat belajar tetap berjalan. Selain itu motivasi mengarahkan dan mengendalikan tujuan peserta didik sehingga dapat melengkapi suatu tugas yang diberikan. Sejalan dengan beberapa hasil penelitian sebelumnya yaitu menurut Aji (2013) bahwa ada pengaruh positif motivasi berprestasi terhadap prestasi hasil belajar peserta didik; Lee (2010) menemukan bahwa motivasi belajar berpengaruh signifilan positif terhadap prestasi belajar dan kesimpulan peneliitian yang dikemkakan oleh Sugiayanto (2009) kontribusi motivasi berprestasi terhadap prestasi akademik menunjukkan bahwa semakin tinggi motivasi berprestasi maka prestasi akademik akan semakin tinggi pula. Kesesuaian hasil penelilitian ini dengan hasil penelitian sebelumnya memberikan penguatan bahwa motivasi berprestasi sangat berpengaruh terhadap hasil belajar peserta didik. Peserta didik yang memiliki motivasi berprestasi tinggi akan memperoleh hasil belajar yang tinggi pula.

Oleh karena ada perbedaan hasil belajar peserta didik yang memiliki motivasi berprestasi tinggi, sedang dan rendah, maka dapat disimpulkan bahwa ada pengaruh motivasi berprestasi terhadap hasil belajar peserta didik kelas XI IPA SMA Negeri 6 Takalar .

\section{Ada interaksi Pengaruh model pembelajaran terhadap hasil belajar kimia peserta didik kelas XI IPA SMA Negeri 6 takalar pada pokok bahasan Hidrokarbon.}

Hasil analisis statistik deskripsi menunjukkan bahwa pada kelas yang dibelajarkan model pembelajaran inkuiri terbimbing, pembelajaran langsung dan discovery learning yang memiliki nilai ratarata hasil belajar tinggi adalah peserta didik yang memiliki motivasi berprestasi tinggi, yang memiliki nilai rata-rata hasil belajar sedang adalah peserta didik yang memiliki motivasi berprestasi sedang demikian pula yang memiliki nilai rata-rata hasil belajar rendah adalah peserta didik yang memiliki motivasi berprestasi rendah pula. 
Analisis statistik inferensial menunjukkan bahwa tidak ada perbedaan selisih hasil belajar peserta didik antara peserta didik yang memiliki motivasi berprestasi tinggi, sedang dan rendah dan model pembelajaran dalam mempengaruhi hasil belajar peserta didik. Tidak adanya selisih hasil belajar peserta didik menunjukkan bahwa tidak terdapat interaksi antara model pembelajaran dan motivasi berprestasi dalam mempengaruhi hasil belajar.

Dapat dilihat pula pada gambar 1 bahwa peserta didik yang memiliki motivasi berprestasi tinggi rata-rata hasil belajarnya tinggi pula, baik pada peserta didik yang dibelajarkan dengan model pembelajaran inkuiri terbimbing, pembelajaran langsung maupun discovery learning. Ketiga model pembelajaran yang menunjukkan hasil belajar yang baik adalah model pembelajaran inkuiri terbimbing karena hasil belajar peserta didik yang diperoleh paling tinggi baik pada kategori motivasi berprestasi tinggi, sedang ataupun rendah dibandingkan dengan model pembelajran langsung dan discovery learning.Peserta didik yang memiliki motivasi berprestasi tinggi dapat diidentifikasi melalui indikatorindikator motivasi berprestasi itu sendiri yaitu peserta didik yang memiliki motivasi berprestasi tinggi setiap pembelajaran selalu berorientasi sukses, berorientasi ke depan, suka tantangan dan tangguh, sehingga peserta didik yang memiliki motivasi berprestasi tinggi lebih memusatkan perhatiannya dalam merumuskan tujuan belajar yang akan dicapai dibandingkan dengan peserta didik yang memiliki motivasi berprestasi sedang dan rendah. Peserta didik yang memiliki motivasi berprestasi sedang atau rendah lebih cenderung mengabaikan prestasi dan sangat susah terlibat dalam proses pembelajaran baik pada model pembelajaran inkuiri terbimbing, pembelajaran langsung maupun discovery learning.

Tidak adanya perbedaan antara selisih hasil belajar peserta didik yang memiliki motivasi berprestasi tinggi, sedang dan rendah pada model pembelajaran inkuiri terbimbing, pembelajaran langsung maupun discovery learning, berarti model pembelajaran mempengaruhi hasil belajar yang berbeda berdasarkan tingkat motivasi berprestasi peserta didik. Peserta didik yang dibelajarkan dengan menggunkan model inkuiri terbimbing, pembelajaran langsung maupun discovery learning hasil belajarnya tergantung dari tingkat motivasi berprestasi yang dimiliki yaitu hasil belajar tinggi apabila peserta didik memiliki motivasi berprestasi tinggi, hasil belajar sedang apabila peserta didik memiliki motivasi berprestasi sedang dan rendah apabila peserta didik memiliki motivasi berprestasi rendah. Hal ini sama dengan penelitian yang dilakukan oleh (Syamsu Rijal, 2015) bahwa tidak ada interaksi antara model pembelajaran dan motivasi berprestasi terhadap hasil belajar peserta didik kelas XI IPA SMA Negeri 1 Namlea pada materi pokok asam basa.

\section{SIMPULAN DAN SARAN}

Berdasarkan hasil penelitian dan pembahasan hasil penelitian, maka dapat disimpulkan bahwa terdapat pengaruh model pembelajaran terhadap hasil belajar peserta didik kelas XI IPA SMA Negeri 6 Takalar pada materi Hodrokarbon tetapi tidak terjadi interaksi antara model pembelajaran dan motivasi berprestasi dalam mempengaruhi hasil belajar peserta didik kelas XI IPA SMA Negeri 6 Takalar pada materi Hidrokarbon

\section{DAFTAR RUJUKAN}

Aji, Swanida Mannik. 2013. Pengaruh motivasi berprestasi terhadap prestasi belajar akuntansi Siswa kelas $\mathrm{X}$ akuntansi SMKN 1 Batang tahun pelajaran 2012/2013. Skripsi. Surakarta: Pendidikan Kimia UNS

Fajariyah, Nur. Budi utami, Haryono. 2016. Penerapan Model Pembelajaran Inkuiri Terbimbing untuk Meningkatkan kemampuan berpikir kritis dan prestasi belajar pada materi kelarutan dan hasil kali kelarutan 
siswa kelas XI SMA Al Islam 1 Surakarta Tahun Pelajaran 2014/2015. Jurnal Pendidikan Kimia Universitas Sebelas Maret vol.5 No 2 Tahun 2016 hal 89-97peserta didik kelas

Greenwald, I. 2014. Using Inquiri-based Teaching to built Critikal Thinking Skill and Intelectual Engagement. Journal Departemen of Biologi Sciences and Sciences Education, 12(2): A100-A106

Ilahi, M. 2012. Pembelajaran Discovery. Jogyakarta: Diva Press

Julistiawati, A., Widya, S.P., dan Lusi. Keterampilan berpikir level C4, C5 \&C6 Revisi Taksonomi Bloom Siswa kelas X-3 SMAN 1 Sumenep Penerapan Model Pembelajaran Inkuiri Pokok Bahasan Larutan Elektrolit dan non elktrolit. UNESA Journal of Chemical Education Surabaya, 2(2) 57-62

Lee, I-Chao. 2010. The Efek Of Learning Motivation, Total Quality Teaching and peer-asissted Learning on Stdy Achievement: Empirical Analysis from Vocational Universities or Colleges Stdents Taiwani. The journal of Human Resource and Adult Learning, 6(2):69

Mubarok, C. 2014. Penerapan Model Pembelajaran Discovery Learning Terhadap Hasil Belajar Siswa Kelas $X$ di SMK Negeri 2 Surabaya Tahn Pelajaran 2013/2014. Jurnal Pendidikan Teknik Elektro 2(1): 215 221

Nugrahaeni dkk. 2017. Penerapan Model Pembelajaran Discovery Learning Untuk Meningkatkan Kemampuan Berpikir Kritis Dan Hasil Belajar Kimia SMA Negeri 2 Singaraja di kelas XI MIA 2 semester gasal tahun ajaran 2016/2017. Jurnal Pendidikan Kimia Indonesia. Volume 1, Nomor 1.

Nurhayati, dkk. 2013. Efektivitas Pembelajaran Dengan Metode Drill
And Practice Dan Learning Cycle 5E Disertai Media Pembelajaran Crossword pizzle Terhadap Prestasibelajar Siswa Pada Materi Pokok hidrokarbon Kelas X Semester Genap SMA Negeri Kebak Kramat. Jurnal Pendidikan Kimia Universitas Sebelas Maret.vol 2. No.3. hal 191-198

Putrayasa, dan Nyoman. I. M. 2014. Pengaruh Model Pembelajaran Discovery Learning dan Minat Belajar terhadap Pemahaman Konsep IPA. Journal of Chemical Education Undiksa, 1(2)67-72.

Rahman, K., Andini, S., dan Rahma. 2014. Pengaruh Penggunaaan discovery Learning terhadap Kemampuan Analogi Matematika Siswa SMA. Jurnal Ilmiah Program Study Kimia STKIP Bandung, 3(1) 33-55.

Rahmadani, Annisa Zewri. 2017. Identifikasi Kesulitan Siswa Kelas XI MIPA SMAN 1 Kandangan pada Materi Hidrokarbon. Skripsi. Malang: UNEM

Rijal, Syamsu. 2014. Pengaruh Model Pembelajaran Dan Motivasi Berprestasi Belajar Kimia Materi Pokok Larutan Asam Basa Kelas XI IPA SMA negeri 1 Namlea. Tesis. Makassar: UNM.

Sanjaya, W. 2006. Startegi Pembelajaran berorientasi Standar Proses Pendidikan. Jakarta: Kencana Prenada Media Grup.

Sochibin, A., Indah D.W.,dan Indriani. 2009. Penerapan pembelajaran Inquri Terbimbing untuk Meningkatkan Pemahaman dan Keterampilan Berpikir Kritis SMA. Jurnal Pendidikan Kimia Indonesia FPMIPA Universitas Negeri Semarang, 5(1)96-101.

Shuaili, A dan Johnstone. H. 2001. Learning in Laboratory; some thoughts from the Literature. Journal Education 
Chemistry University of Glasgow. ISSN 1369-5614. 5(2), 42-91.

Sugiyanto. 2009. Kontribusi Motivasi Berprestasi Terhadap Prestasi Akademik Siswa Kelas Xi Sma Negeri 10 Semarang. Paradigma, No. 08 Th. IV, Juli 2009 • ISSN 1907-297X.

Sulistyowati, A., Ahmad, S., dan Kartini, C.S. 2012. Efektifitas Model Pembelajaran Guided Discovery Learning terhadap Kemampuan Berpikir Peserta Didik. Jurnal Pendidikan Kimia UNS, 2(1)49-55

Sumarni, dkk. 2017. Pengaruh Model Pembelajaran Inkuiri Terbimbing Terhadap Hasil Belajar Kognitif Peserta Didik di SMA Negeri 1 Manokwari (Studi pada pokok bahasan Kelartan dan hasil kali kelarutan). Jurnal Nalar Pendidikan.Volume V, hal 21,No 1. ISSN 2339-0749.

Taiyeb, A. Musawwir dkk. 2012. Analisis Motivasi Berprestasi Siswa SMA Negeri 8 Makassar dalam Belajar Biologi. Jurnal Bionature Jurusan Biologi FMIPA UNM, Volume 13 No.2 oktober 2012 hal 77-82 (diakses 3 Mei 2018)
Wuryani, dkk. 1989. Psikologi Pendidikan. Jakarta : Depdikbud 